\title{
EVALUATION OF AIR AND SOIL POLLUTION USING THE BIOMARKER MORINGA OLEIFERA IN JEDDAH CITY, SAUDI ARABIA
}

\author{
Al KhaZAN, M. M. \\ Department of Biological Science, Faculty of Science, King Abdulaziz University \\ 21589 Jeddah, Saudi Arabia \\ e-mail: m.kzanm@gmail.com; phone: +96-650-569-4816 \\ (Received 25 ${ }^{\text {th }}$ Mar 2018; accepted 25 $5^{\text {th }}$ May 2018)
}

\begin{abstract}
Physiological processes, photosynthesis, carbon and nitrogen metabolism, osmotic adjustment and secondary metabolites are known to be affected by air and soil pollutants. The present study was designed to evaluate the impact of air and soil pollution in Jeddah city, Saudi Arabia, on the physiological processes of Moringa oleifera. Four accessions differing in their pollution intensity were selected for this study (S1-S4). Elemental analysis revealed that $\mathrm{Pd}, \mathrm{Cu}, \mathrm{Mn}, \mathrm{Cr}, \mathrm{Fe}$ and $\mathrm{Zn}$ were the main soil pollutants in study accessions and trees growing in S2 have accumulated large quantities of these metals in their leaves. The physiological response to environmental pollution in $M$. oleifera tree was found to be dependent on pollution intensity. The heavily polluted accession showed a different response from the rest of accessions. As an adaptive strategy to environmental stress, this site has shown an increase in some metabolites such as lipids, flavonoids, free amino acids, alkaloids and saponins. However, some metabolites were decreased in response to pollution intensity such as soluble sugars and proteins, ascorbic acid, and terpenoids.
\end{abstract}

Keywords: Moringa oleifera, heavy metals, phytotoxicity, physiological response, antioxidant capacity

\section{Introduction}

Moringa (Moringa oleifera Lam.) is the most broadly cultivated species within Moringaceae family and is known as a rapidly-growing tree. It is commonly distributed in the sub-Himalayan parts of India, Pakistan, Bangladesh and Afghanistan. It has been introduced and become naturalized in many other parts of the world including Arabian peninsula. Moringa oleifera has many common names as the horseradish tree, drumstick tree, benzolive tree, kelor, marango, mlonge, moonga, and many other synonyms (Fahey, 2005). Moringa oleifera is widely cultivated for many purposes as efficient food stuff, biofuel production, and other implementations. Traditionally, it is used in therapeutic objectives around the world due to actual manifestations. These advantages have been related to metabolites like phenolics, vitamins and proteins (Health, 2005; Adedapo et al., 2009). Moringa oleifera offers a rich and unusual mixture of nutrients in its leaves, pods and seeds, amino acids that possess many therapeutic activities like antioxidant, anti-aging and anti-inflammatory. Moringa is sometimes called "Mother's Best Friend" and "Miracle Tree" as it has been advised as a complementary to treat malnutrition (Sreelatha and Padma, 2009).

In fact, moringa is said to provide 7 times more vitamin $\mathrm{C}$ than oranges, 10 times more vitamin A than carrots, 17 times more calcium than milk, 9 times more protein than yoghurt, 15 times more potassium than bananas and 25 times more iron than spinach (Rockwood et al., 2013). The leaves of $M$. oleifera has been established as a rich source of phenolics and glucosinolates (Amaglo et al., 2010), minerals like iron, calcium, phosphorus and copper, (Saini et al., 2014a), tocopherols (Saini et al., 2014b) and antioxidants (Dillard and German, 2000). It also contains high concentrations of 
ascorbic acid, estrogenic substances and beta-sitosterol, vitamins $\mathrm{A}, \mathrm{B}$ and $\mathrm{C}, \alpha-$ tocopherol, riboflavin, nicotinic acid, pyridoxine, $\beta$-carotene, protein, and essential amino acids such as methionine, cystine, tryptophan and lysine (Rajput et al., 2017). These components have pharmacological potentials like antimicrobial, anticancer, antihyperlipidemic, antidiabetic, antiulcer, analgesic, antifertility, anticonvulsant and hepatoprotective (Ganatra et al., 2012).

Global awareness of air pollution has been rising due to its massive danger to public health. World Health Organization (WHO) reported that annual concentration of ambient air pollution was increased worldwide by $8 \%$ during the recent five years (Nakao et al., 2017). In regard to plants, unrestrained use of fossil fuels in industries and transport sectors has led to the increase in concentrations of gaseous pollutants such as $\mathrm{SO}_{2}, \mathrm{NO}_{2}$, etc. (Rai et al., 2011). It is a known fact that $60 \%$ of air pollution in city is caused by automobiles only. On sensitive species of both plants and animals, the effect of these pollutants is observed at acute level. Response of plants towards air is being assessed by the air pollution tolerance index (APTI). Some plant species and varieties are so sensitive that they can be easily used as biological indicators or monitors of specific pollutants. They can further assist the planner in managing the urban cities (Horaginamani and Ravichandran, 2010).

With the extension of the urban expansion of the city of Jeddah, Kingdom of Saudi Arabia (KSA), many human requirements led to the accumulation of various wastes containing hazardous and non-hazardous components. The lack of proper disposal of those wastes cause environmental disasters on all surroundings. Solid waste management studies have shown that the amount of solid household waste produced per individual in industrialized and developed countries ranges from 2 to $2.5 \mathrm{~kg} / \mathrm{day}$. The World Health Organization classified the Arab Gulf countries among the rich countries characterized by the rise of solid waste for individuals, which led to the emergence of the problem of open and closed garbage dump sites. Due to the fact that plants play an effective role in purifying the environment of pollutants, $M$. oleifera was selected for this study. It was noted that its fruits and leaves are palatable by the expatriate workers, despite of it was planted in areas close to garbage dumps and in heavy traffic roads. This study provides an overview on the nutritional value, antioxidant capacity, secondary metabolites, as well as heavy metals exclusion capacity from air and soil by M. oleifera in four differentially polluted accessions in Jeddah city, KSA.

\section{Materials and methods}

Green leaves of $M$. oleifera tree were collected during the summer season of 2017 from four different accessions in Jeddah city, KSA. The first accession (S1) was a double public road passing by cars $(21.33 .32 \mathrm{~N} ; 39.10 .33 \mathrm{E})$, the second accession (S2) was a polluted area by flaming fires, factories wastes and random waste disposal (21.21.16 N; 39.13.09 E). The third accession (S3) was a narrow bystreet with rare traffic $(21.33 .29 \mathrm{~N} ; 39.10 .32 \mathrm{E})$ and the fourth accession (S4) was a secondary street with average traffic $(21.33 .49 \mathrm{~N} ; 39.10 .44 \mathrm{E})$. The map of different experimental sites is provided in Photo 1. The mature and fully expanded leaves were collected from the top branches of the trees in the study sites. A total of 250 leaves were collected from 5 trees at each experimental site. Leaf samples were washed with tap water several times and once with distillated water, placed in an air-forced oven at $60{ }^{\circ} \mathrm{C}$ for five days. Dried samples were grinded into fine powder by an electrical mixer, sieved through $0.2 \mathrm{~mm}$ 
sieve and stored in paper bags for analysis. Soil samples were collected at the time of leaves collections from the study sites. Soil samples were collected from the surface soil layers with a depth of about 0 to $20 \mathrm{~cm}$ at the tree rhizosphere. Soil samples were replicated three times per each experimental site. The collected soil samples air dried and sieved for physical and chemical characterization.

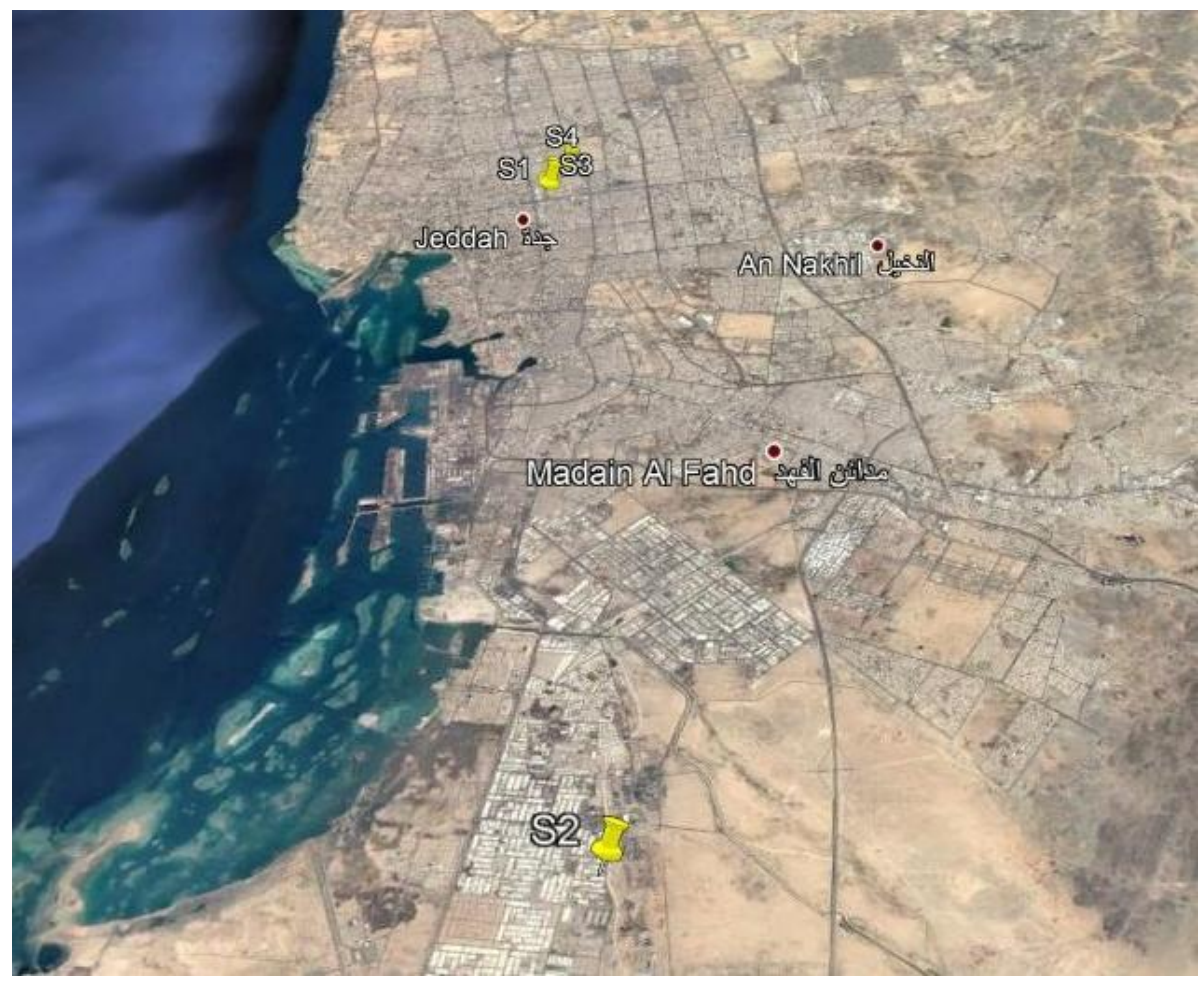

Photo 1. A satellite image of the four experimental sites

\section{Mineral analysis of plant and soil samples}

Plant and soil samples were digested with a mixture of $69 \% \mathrm{HNO}_{3}$ and $30 \% \mathrm{H}_{2} \mathrm{O}_{2}$ $(5: 2 \mathrm{v} / \mathrm{v})$. The mineral content concentrations in digested solutions were determined using inductively coupled plasma-optical emission spectroscopy (Polyscan 61E, Thermo Jarrell-Ash Corp., Franklin, MA, USA).

\section{Estimation of photosynthetic pigments}

Total photosynthetic pigments; $\mathrm{Chl} \mathrm{a}, \mathrm{Chl} \mathrm{b}$ and carotenoids, were extracted from moringa leaves by grinding in cold acetone (80\%) using pre-chilled mortar and pestle. The extracted pigments were centrifugated at $3000 \mathrm{rpm}$ for $15 \mathrm{~min}$ and quantified according to the method prescribed by Metzner et al. (1965). The quantified pigments were expressed as $(\mu \mathrm{g} / \mathrm{g} \mathrm{dw})$.

\section{Preparation of methanolic extract}

The fine powdered plant tissues ( $5 \mathrm{~g}$ for each sample) were extracted with $50 \mathrm{ml}$ of $95 \%$ methanol for $12 \mathrm{~h}$ at room temperature in an orbital shaker (Panasonic, MIR-S100, Japan). The extracts were filtered through Whatman No. 1 filter paper. The residues 
were extracted twice again as previously and extracts were combined. The combined extracts were concentrated under reduced pressure at $40{ }^{\circ} \mathrm{C}$ using rotary evaporator (Heidolph) and adjusted to $50 \mathrm{ml}$ by methanol. Extracts were stored in glass vials at $4{ }^{\circ} \mathrm{C}$ until the time of analysis. All the spectrophotometric measurements were carried out using JENWAY 6315 UV/Visible Spectrophotometer (Japan).

\section{Determination of total soluble carbohydrates}

The total soluble carbohydrates content in the methanolic extract of plant powder was measured according to the phenol-sulfuric acid method using glucose as a standard sugar (Dubois et al., 1965) and expressed as $\mathrm{mg} / \mathrm{g} \mathrm{dw}$.

\section{Determination of total soluble proteins}

Total soluble protein content of the extract was measured using bovine serum albumin (BSA) as a protein standard. The extract or the standard protein was mixed with Coomassie brilliant blue G250 reagent, the absorbance was measured at $595 \mathrm{~nm}$ and the results were expressed as $\mathrm{mg} / \mathrm{g}$ dw (Bradford, 1976).

\section{Lipid quantification}

Total lipid content of leaf powders was extracted by the method reported by Bligh and Dyer (1959). The samples were stirred in a chloroform and methanol mixture (2:1 $\mathrm{v} / \mathrm{v}$ ) over $48 \mathrm{~h}$, the powder was filtered off and washed with additional chloroform. This was repeated three times. The volatiles were removed under reduced pressure and the lipid content was expressed as $\mathrm{mg} / \mathrm{g} \mathrm{dw}$.

\section{Determination of flavonoids}

Colorimetric aluminum chloride method was used for flavonoid determination (Chang et al., 2002). Leaf extract was mixed with $1.5 \mathrm{ml}$ of methanol, $0.1 \mathrm{ml}$ of $10 \%$ $\mathrm{AlCl}_{3}, 0.1 \mathrm{ml}$ of $1 \mathrm{M} \mathrm{K}$-acetate and $2 \mathrm{ml}$ of distilled water. The absorbance of the reaction mixture was measured at $417 \mathrm{~nm}$. Total flavonoids were calculated as quercetin from a calibration curve and expressed as $\mathrm{mg} / \mathrm{g} \mathrm{dw}$.

\section{Determination of ascorbic acid (AA)}

Ascorbic acid was extracted by homogenization in 5\% sulfosalicylic acid. The resultant homogenate was centrifugated at $5000 \mathrm{rpm}$ for $15 \mathrm{~min}$ and $1 \mathrm{ml}$ of the supernatant was incubated with $2 \mathrm{ml} 2 \%$ Na-molybdate, $2 \mathrm{ml} 0.15 \mathrm{~N} \mathrm{H}_{2} \mathrm{SO} 4$ and $1 \mathrm{ml}$ $1.5 \mathrm{mM} \mathrm{Na} \mathrm{HPO}_{4}$ at $60{ }^{\circ} \mathrm{C}$ for $40 \mathrm{~min}$. Absorbance was measured at $660 \mathrm{~nm}$ and ascorbic acid content was calculated as $\mathrm{mg} / \mathrm{g} \mathrm{dw}$ using a prepared calibration curve by ascorbic acid (Oser, 1979).

\section{DPPH radical scavenging activity}

The antioxidant capacity of the obtained methanolic extracts was measured by bleaching of the purple coloured solution of 1,1- diphenyl-2-picrylhydrazyl radical (DPPH) according to the method of Sun et al. (1988). Methanolic extracts were added to $0.2 \mathrm{mM} \mathrm{DPPH}$ and incubated at room temperature for $30 \mathrm{~min}$, then the absorbance was measured against a blank at $517 \mathrm{~nm}$. DPPH scavenging activity was calculated from the formula: $(\%)=100$ [(A blank-A sample $) / A$ blank $]$. 


\section{Free amino acids estimation}

Amino acids content of the methanolic extracts was estimated by ninhydrin assay using glycine as a standard amino acid (Lee and Takahashi, 1966). Samples were mixed with ninhydrin-citrate buffer-glycerol mixture $(0.5 \mathrm{ml} 1 \%$ ninhydrin solution in $0.5 \mathrm{M}$ citrate buffer $\mathrm{pH} 5.5,1.2 \mathrm{ml}$ of $55 \%$ glycerol and $0.2 \mathrm{ml}$ of $0.5 \mathrm{M}$ citrate buffer). The mixture was then shaken and boiled in a water bath for $12 \mathrm{~min}$, cooled, shaken well, and the absorbance was measured at $570 \mathrm{~nm}$ and the result was calculated as $\mathrm{mg} / \mathrm{g} \mathrm{dw}$.

\section{Determination of phenolic compounds}

The total phenolic content of methanolic extracts was determined using FolinCiocalteu's reagent (Jindali and Singh, 1975). Aliquot of extracts was mixed with $0.1 \mathrm{ml}$ Folin-Ciocalteu's reagent and $1 \mathrm{ml} \mathrm{20 \%} \mathrm{Na}_{2} \mathrm{CO}_{3}$, then completed up to a known volume with dist. water. Thereafter, the absorbance was measured at $650 \mathrm{~nm}$ after 30 min and gallic acid was used as a standard phenol and phenol content was expressed as $\mathrm{mg} / \mathrm{g} \mathrm{dw}$.

\section{Determination of alkaloids}

Alkaloids were determined using the method of Harbourne (1984). Alkaloids were extracted by a mixture of acetic acid and ethanol $(1: 9 \mathrm{v} / \mathrm{v})$. The mixture filtered and the extract was concentrated on a water bath. Concentrated ammonium hydroxide was added dropwise to the extract until the precipitation was complete. The precipitate was collected, washed with dilute ammonium hydroxide and then filtered. The residue is the alkaloid, which was dried and weighed then expressed as $\mathrm{mg} / \mathrm{g} \mathrm{dw}$.

\section{Estimation of saponins}

Saponin content was estimated quantitatively by the method described by Hiai et al. (1975) in the methanolic extract. Aliquot of $0.5 \mathrm{ml}$ extract was mixed with $0.5 \mathrm{ml}$ of $8 \%$ vanilline. The mixture was placed in an ice bath and mixed with $5 \mathrm{ml}$ of $72 \% \mathrm{H}_{2} \mathrm{SO}_{4}$, then heated in a water bath at $60{ }^{\circ} \mathrm{C}$ for $10 \mathrm{~min}$ followed by cooling in the ice-cold water bath. The content of saponins was calculated as $\mathrm{mg} / \mathrm{g} \mathrm{dw}$ using a standard curve by cholesterol.

\section{Total tannins determination}

The tannin contents of methanolic extracts were determined by method of Broadhurst and Jones (1978) using tannic as a standard. Aliquot of $400 \mu \mathrm{l}$ extract is added to $3 \mathrm{ml}$ of $4 \%$ vanillin in methanol and $1.5 \mathrm{ml}$ of concentrated $\mathrm{HCl}$. After $15 \mathrm{~min}$ of incubation the absorbance was read at $500 \mathrm{~nm}$. Tannin content was calculated as $\mathrm{mg} / \mathrm{g} \mathrm{dw}$.

\section{Total terpenoids determination}

Aliquot of $1.5 \mathrm{ml}$ chloroform was added to $200 \mu \mathrm{l}$ extract, the mixture was vortexed well, then $100 \mu \mathrm{l}$ conc. $\mathrm{H}_{2} \mathrm{SO}_{4}$ were added and incubated at dark for $2 \mathrm{hs}$. The supernatant was decanted and $1.5 \mathrm{ml}$ of $95 \%$ methanol was added, followed by vortexing until all the precipitate dissolved completely and the absorbance was measured at $538 \mathrm{~nm}$. Total terpenoids were calculated using a standard curve prepared by linalool and expressed as $\mathrm{mg} / \mathrm{g} \mathrm{dw}$ (Ghorai et al., 2012). 


\section{Statistical analysis}

Results were statistically analyzed by one-way ANOVA using Costat under Windows software. Significant differences among accessions were calculated by Duncan's multiple range test at $0.05 \%$. Results were represented as mean of three replications \pm standard deviation $(\mathrm{SD})$.

\section{Results}

Table 1 shows the physical properties of soil samples collected from $M$. oleifera various growth habitats (accessions). A highly significant change was observed in electrical conductivity (EC) as a measure of soluble salts in the soil and salinity level. The uppermost EC value was quantified for S4 and S1 soil samples (897 and $860 \mu \mathrm{S} / \mathrm{cm}$, respectively). Meanwhile, the lowermost values were observed in soil samples of S3 and S2 (335.3 and $345.7 \mu \mathrm{S} / \mathrm{cm}$, respectively). As for soil reaction, the results showed that $\mathrm{S} 1$ soil was slightly acidic (6.9), S2 was exactly neutral (7), however S3 and S4 soils were marginally alkaline (7.2).

Table 1. Physical properties (EC and $\mathrm{pH}$ ) of soil samples collected from growth accessions of M. oleifera trees in Jeddah city

\begin{tabular}{c|c|c}
\hline No & $\mathbf{E C}(\boldsymbol{\mu S} / \mathbf{c m})$ & pH \\
\hline S1 & $860.0 \pm 7.0 \mathrm{c}$ & $6.9 \pm 0.2 \mathrm{a}$ \\
\hline S2 & $345.7 \pm 0.6 \mathrm{~b}$ & $7.0 \pm 0.0 \mathrm{ab}$ \\
\hline S3 & $335.3 \pm 0.6 \mathrm{a}$ & $7.2 \pm 0.1 \mathrm{c}$ \\
\hline S4 & $897.0 \pm 1.0 \mathrm{~d}$ & $7.2 \pm 0.1 \mathrm{bc}$ \\
\hline
\end{tabular}

The concentrations of various heavy metals ( $\mathrm{Cr}, \mathrm{Pb}, \mathrm{Cu}, \mathrm{Fe}, \mathrm{Mn}$ and $\mathrm{Zn}$ ), as well as some essential elements ( $\mathrm{P}, \mathrm{Ca}, \mathrm{Mg}$ and $\mathrm{K}$ ) in addition to $\mathrm{Na}$ in the soils and leaves of $M$. oleifera collected from four differentially polluted habitats, S1-S4, in Jeddah city, KSA significantly varied (Table 2).

Table 2. Mineral analysis of soil samples and M. oleifera leaves (ppm) exposed to different pollution intensities in Jeddah city

\begin{tabular}{c|c|c|c|c|c|c|c|c}
\hline \multirow{2}{*}{$\begin{array}{c}\text { Metal } \\
\text { concentration } \\
(\mathbf{p p m})\end{array}$} & $\mathbf{5}$ & $\mathbf{S}$ Soil samples & \multicolumn{4}{c}{ Leaf samples } \\
\cline { 2 - 9 } & $\mathbf{S 2}$ & $\mathbf{S 3}$ & $\mathbf{S 4}$ & $\mathbf{S 1}$ & $\mathbf{S 2}$ & $\mathbf{S 3}$ & $\mathbf{S 4}$ \\
\hline $\mathrm{Cr}$ & $1.15^{\mathrm{a}}$ & $0.98^{\mathrm{d}}$ & $1.06^{\mathrm{c}}$ & $1.12^{\mathrm{b}}$ & $0.02^{\mathrm{a}}$ & $0.10^{\mathrm{b}}$ & $0.02^{\mathrm{a}}$ & $0.01^{\mathrm{b}}$ \\
\hline $\mathrm{Pb}$ & $0.50^{\mathrm{c}}$ & $3.63^{\mathrm{a}}$ & $1.13^{\mathrm{b}}$ & $0.21^{\mathrm{d}}$ & $0.25^{\mathrm{c}}$ & $1.95^{\mathrm{a}}$ & $0.41^{\mathrm{d}}$ & $0.01^{\mathrm{b}}$ \\
\hline $\mathrm{Cu}$ & $0.74^{\mathrm{d}}$ & $1.97^{\mathrm{a}}$ & $1.22^{\mathrm{b}}$ & $1.08^{\mathrm{c}}$ & $0.06^{\mathrm{c}}$ & $0.29^{\mathrm{a}}$ & $0.06^{\mathrm{c}}$ & $0.11^{\mathrm{b}}$ \\
\hline $\mathrm{Fe}$ & $865.0^{\mathrm{a}}$ & $818.0^{\mathrm{b}}$ & $766.0^{\mathrm{d}}$ & $785.0^{\mathrm{c}}$ & $6.27^{\mathrm{b}}$ & $18.00^{\mathrm{a}}$ & $0.19^{\mathrm{c}}$ & $6.71^{\mathrm{b}}$ \\
\hline $\mathrm{Mn}$ & $15.4^{\mathrm{c}}$ & $26.4^{\mathrm{a}}$ & $15.90^{\mathrm{bc}}$ & $16.70^{\mathrm{b}}$ & $0.42^{\mathrm{c}}$ & $2.30^{\mathrm{a}}$ & $0.55^{\mathrm{b}}$ & $0.06^{\mathrm{d}}$ \\
\hline $\mathrm{Zn}$ & $1.70^{\mathrm{d}}$ & $2.30^{\mathrm{b}}$ & $3.10^{\mathrm{a}}$ & $1.91^{\mathrm{c}}$ & $0.59^{\mathrm{b}}$ & $6.40^{\mathrm{a}}$ & $0.53^{\mathrm{b}}$ & $0.53^{\mathrm{b}}$ \\
\hline $\mathrm{P}$ & $23.14^{\mathrm{a}}$ & $18.09^{\mathrm{c}}$ & $15.78^{\mathrm{d}}$ & $21.25^{\mathrm{b}}$ & $13.89^{\mathrm{c}}$ & $20.89^{\mathrm{a}}$ & $5.47^{\mathrm{d}}$ & $17.67^{\mathrm{b}}$ \\
\hline $\mathrm{Ca}$ & $296.0^{\mathrm{a}}$ & $182.0^{\mathrm{b}}$ & $141.0^{\mathrm{c}}$ & $106.0^{\mathrm{d}}$ & $60.80^{\mathrm{b}}$ & $37.30^{\mathrm{c}}$ & $170.0^{\mathrm{a}}$ & $172^{\mathrm{a}}$ \\
\hline $\mathrm{Mg}$ & $597.5^{\mathrm{b}}$ & $550.6^{\mathrm{c}}$ & $602.7^{\mathrm{b}}$ & $726.8^{\mathrm{a}}$ & $45.70^{\mathrm{c}}$ & $147.30^{\mathrm{a}}$ & $64.6 .0^{\mathrm{b}}$ & $36.6^{\mathrm{d}}$ \\
\hline $\mathrm{Na}$ & $22.23^{\mathrm{c}}$ & $17.30^{\mathrm{d}}$ & $25.47^{\mathrm{a}}$ & $24.05^{\mathrm{b}}$ & $13.92^{\mathrm{d}}$ & $83.73^{\mathrm{a}}$ & $17.61^{\mathrm{c}}$ & $24.65^{\mathrm{b}}$ \\
\hline $\mathrm{K}$ & $84.80^{\mathrm{b}}$ & $73.10^{\mathrm{c}}$ & $73.30^{\mathrm{c}}$ & $116.0^{\mathrm{a}}$ & $53.90^{\mathrm{c}}$ & $70.10^{\mathrm{b}}$ & $90.20^{\mathrm{a}}$ & $54.1^{\mathrm{c}}$ \\
\hline
\end{tabular}

Means within the same row followed by different letters are significantly different $(\mathrm{P}<0.05)$ 
Difference in heavy metals transport from soils to leaves of $M$. oleifera was remarkable. The most pronounced concentration of metals in soil samples was recorded for $\mathrm{Pb}, \mathrm{Cu}$ and $\mathrm{Mn}$ in S2 soil (3.63, 1.97 and $26.4 \mathrm{ppm}$, respectively), $\mathrm{Cr}$ and Fe in S1 soil (1.15 and $865.0 \mathrm{ppm}$ respectively) and $\mathrm{Zn}$ in $\mathrm{S} 3$ soil $(3.10 \mathrm{ppm})$. The results indicated that soil S4 is less contaminated with heavy metals than the rest of the soils under study. For essential elements, it has been proven that $\mathrm{S} 1$ soil was the richest with $\mathrm{P}$ and $\mathrm{Ca}$ (23.14 and $296.0 \mathrm{ppm}$, respectively) and S4 soil was the richest with $\mathrm{Mg}$ and $\mathrm{K}$ (726.8 and $116.0 \mathrm{ppm}$, respectively). However, the highest $\mathrm{Na}$ concentration was more remarkable in $\mathrm{S} 3$ soil (25.47 ppm).

Estimation of heavy metals and essential minerals in $M$. oleifera leaves distinguished trees grown in S2 accession (heavily polluted by flaming fires, factories waste and random waste disposal) as highly accumulative for these elements. The most prominent concentration in $\mathrm{S} 2$ leaves was observed for $\mathrm{Pb}, \mathrm{Cu}, \mathrm{Fe}, \mathrm{Mn}, \mathrm{Zn}, \mathrm{P}, \mathrm{Mg}$ and $\mathrm{Na}$ (1.95, $0.29,18.0,2.3,6.4,20.89,147.30$ and $83.73 \mathrm{ppm}$, respectively). However, the most prominent concentration of $\mathrm{Ca}$ and $\mathrm{K}$ was observed in $\mathrm{S} 1$ and $\mathrm{S} 3$, respectively $(60.80$ and $90.20 \mathrm{ppm}$ ). Therefore, $M$. oleifera could be used as a biomarker for air and soil pollution in heavily polluted areas like $\mathrm{S} 2$ one.

The ambient air and soil pollution profoundly affected photosynthetic pigments concentration in $M$. oleifera leaves. Chlorophyll a content significantly lowered in S2, $\mathrm{S} 3$ and $\mathrm{S} 4$ accessions (3.90, 3.31 and $3.65 \mu \mathrm{g} / \mathrm{g} \mathrm{dw}$, respectively) comparable to $\mathrm{S} 1$ $(4.71 \mu \mathrm{g} / \mathrm{g} \mathrm{dw})$ (Fig. 1). The most pronounced reduction in Chl a was observed in leaves of S3. For Chl b, the same result was attained, as S1 was higher than other accessions $(1.61 \mu \mathrm{g} / \mathrm{g} \mathrm{dw})$. The least Chl b content was observed in S2 and S4 $(1.41$ and $1.40 \mu \mathrm{g} / \mathrm{g}$ $\mathrm{dw}$, respectively). In contrast to chlorophyll, carotenoids recorded the highest content in S2 leaves $(1.46 \mu \mathrm{g} / \mathrm{g} \mathrm{dw})$.

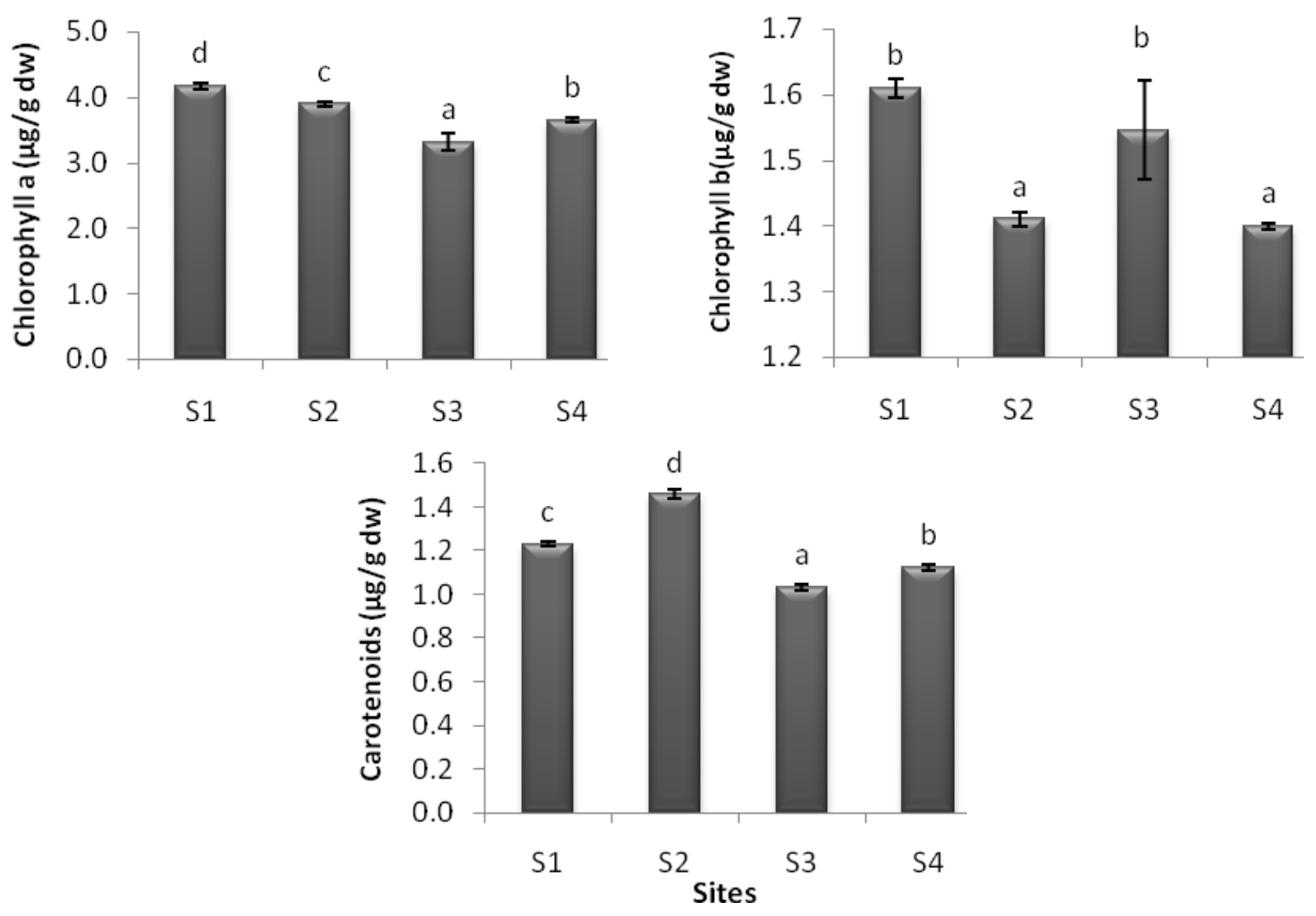

Figure 1. Photosynthetic pigments of $M$. oleifera leaves $(\mu \mathrm{g} / \mathrm{g} d w)$ exposed to different pollution intensities in Jeddah city 
Total soluble sugars content in $M$. oleifera leaves was profoundly varied with the growth site (Fig. 2). The uppermost sugar content was detected in S4 leaves compared to other accessions. However, the least sugar concentration was in leaves of trees growing in $S 1(77.6 \mathrm{mg} / \mathrm{g} \mathrm{dw})$. The same pattern of sugars concentration was perceived for total soluble proteins in the studied accessions. As for total lipids, the leaves of trees growing in S1 and S4 recorded the least content (58.0 and $61.5 \mathrm{mg} / \mathrm{g} \mathrm{dw}$, respectively), whereas those of $\mathrm{S} 2$ and $\mathrm{S} 3$ recorded higher levels $(77.0 \mathrm{mg} / \mathrm{g} \mathrm{dw})$.

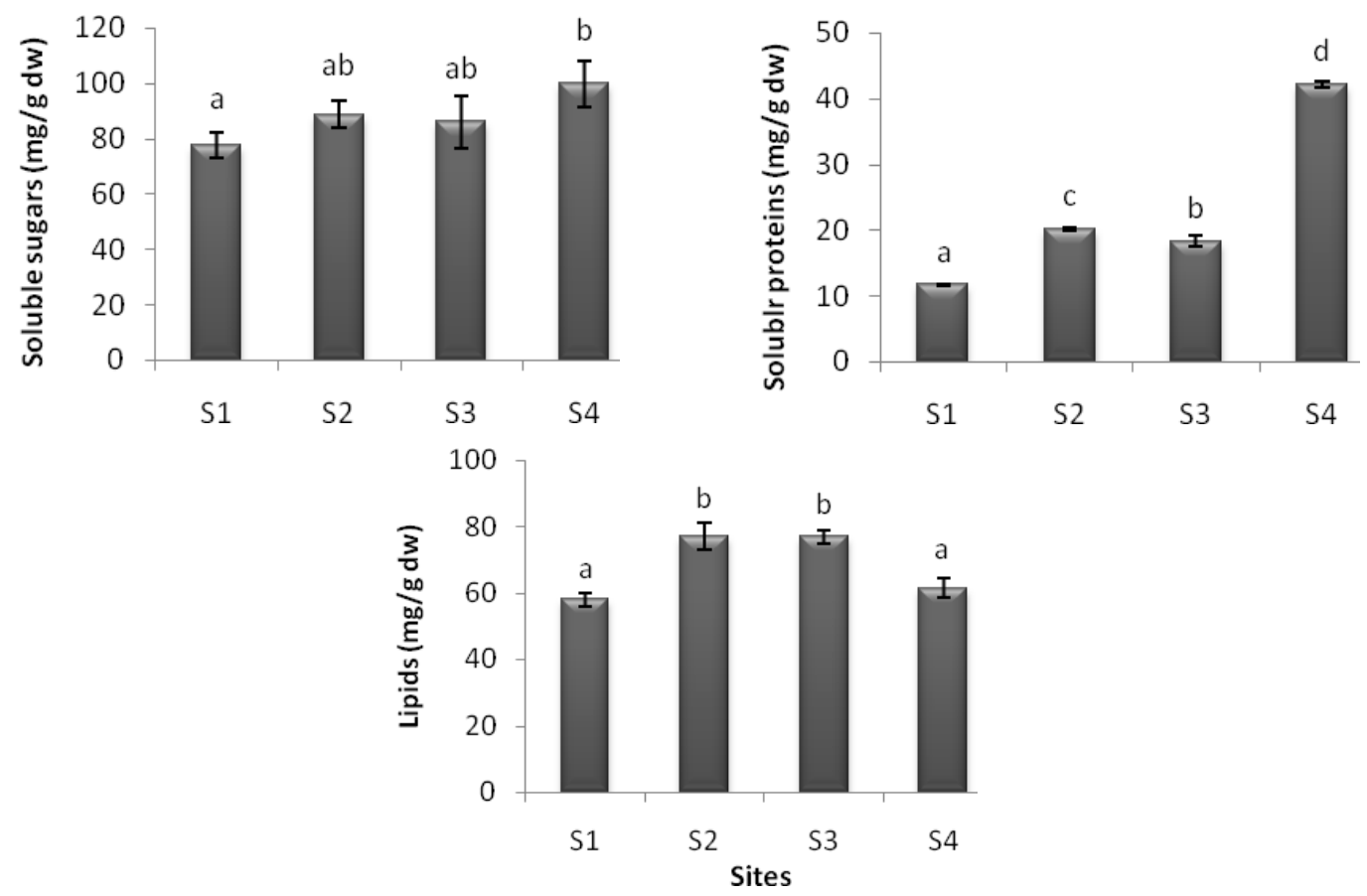

Figure 2. Total soluble sugars, soluble proteins and total lipids of M. oleifera leaves $(\mathrm{mg} / \mathrm{g} d w)$ exposed to different pollution intensities in Jeddah city

Data in Figure 3 illustrate the non-enzymatic antioxidant activities of $M$. oleifera leaves growing at different accessions in Jeddah city (KSA), represented in flavonoids, ascorbic acid and total free radical scavenging activity (DPPH). The highest flavonoids content $(5.76 \mathrm{mg} / \mathrm{g} \mathrm{dw})$ was ascertained in S2 leaves, however the least content $(2.57 \mathrm{mg} / \mathrm{g} \mathrm{dw})$ was in S1. Ascorbic acid level ranged from lower value $(19.11 \mu \mathrm{mol} / \mathrm{g}$ $\mathrm{dw})$ in $\mathrm{S} 3$ to higher value $(23.68 \mu \mathrm{mol} / \mathrm{g} \mathrm{dw})$ in $\mathrm{S} 1$ leaves. Free radical scavenging (DPPH) activity differed in plant leaves with the difference in growth position. The most pronounced DPPH activity (35.7\%) was detected in S4 leaves, meanwhile the least activity (24.7\%) was recorded in S1 leaves.

Accumulation of free amino acids, phenolic compounds and alkaloids in $M$. oleifera leaves in response to pollution intensity in four geographical accessions in Jeddah city is summarized in Figure 4. Total content of free amino acids oscillated between 61.9 and $187.0 \mathrm{mg} / \mathrm{g} \mathrm{dw}$ in the studied plant leaves. Accumulation of free amino acids was more pronounced in S2 (highest value), nevertheless the least content was detected in S1 leaves. Study results revealed a significant difference among study accessions in $M$. oleifera leaves phenolic content. The highest phenolic content was detected in the leaves of S4 and S2 (78.39 and $76.75 \mathrm{mg} / \mathrm{g} \mathrm{dw}$, respectively), however the lowermost 
content was in leaves of S1 (39.29 mg/g dw). For alkaloids content, the change with the growth accession was highly significant. Accession S2 recorded the maximum rate of alkaloids accumulation $(51.0 \mathrm{mg} / \mathrm{g} \mathrm{dw})$ in $M$. oleifera leaves, while accession S3 showed the lowest alkaloids content $(25.0 \mathrm{mg} / \mathrm{g} \mathrm{dw})$ in $M$. oleifera leaves.
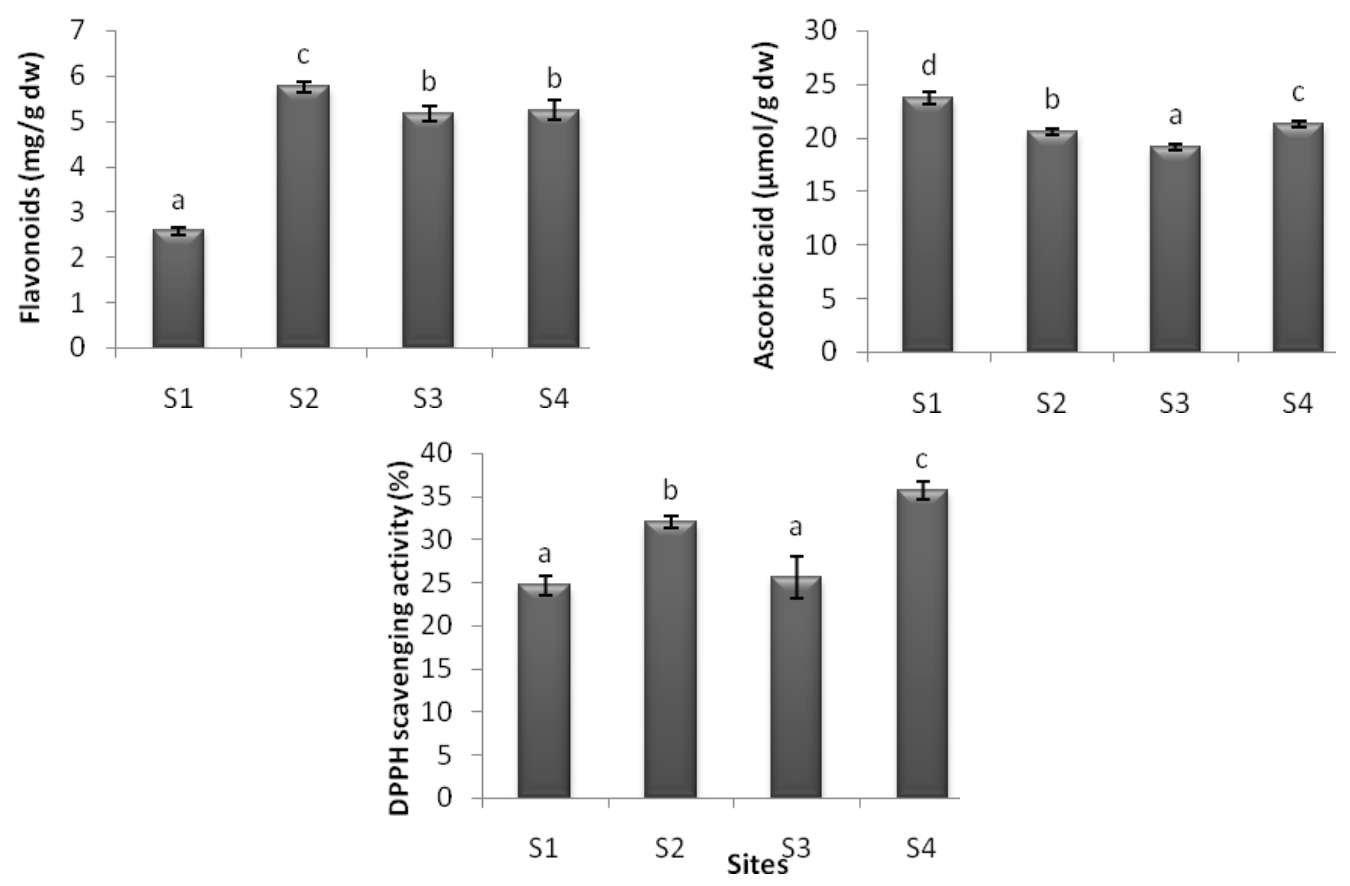

Figure 3. Non-enzymatic antioxidant activities of M. oleifera leaves (flavonoids, ascorbic acid and DPPH activity) exposed to different pollution intensities in Jeddah city

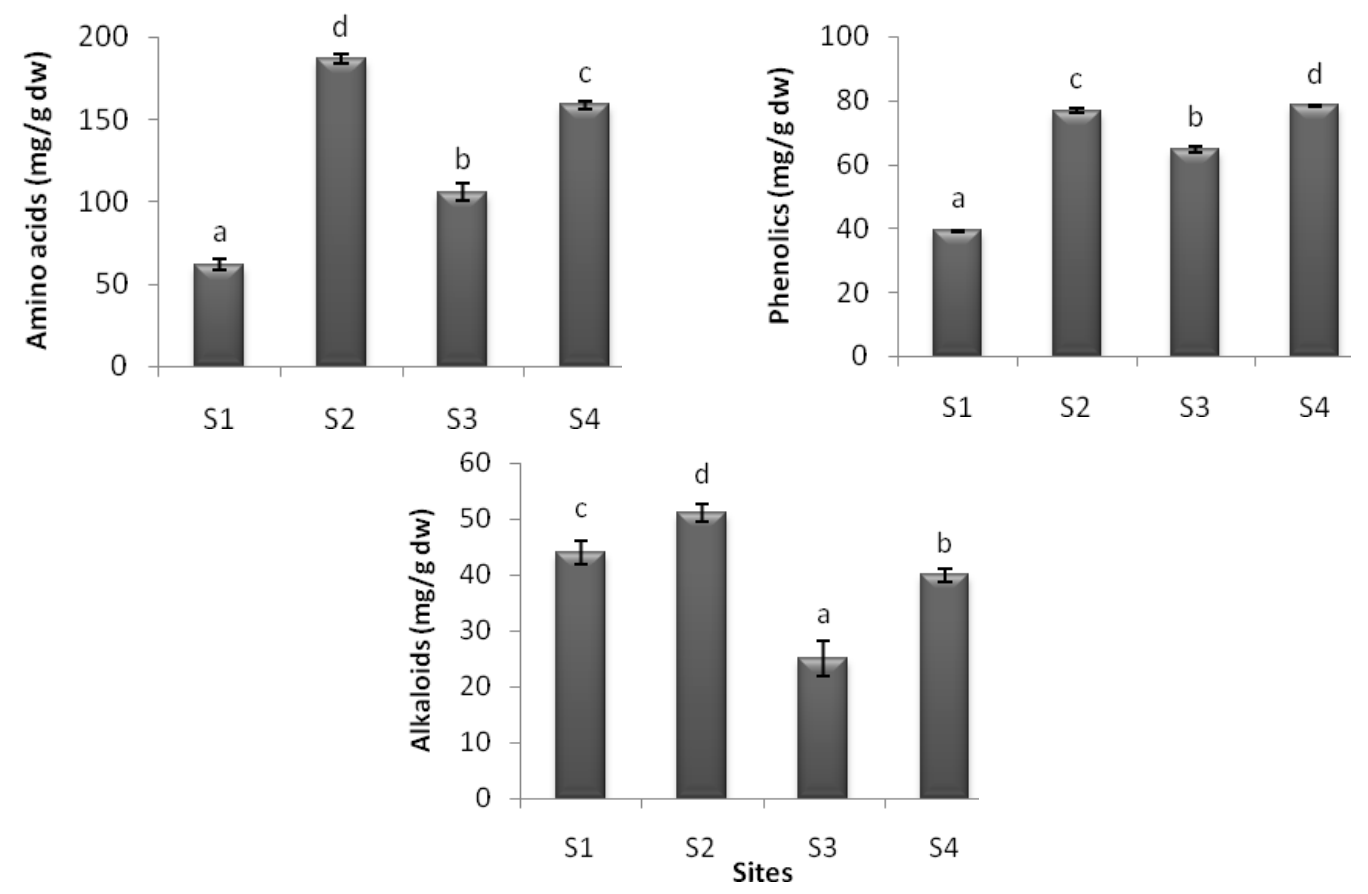

Figure 4. Variations in amino acids, phenolic compounds and alkaloids contents ( $\mathrm{mg} / \mathrm{g} \mathrm{dw}$ ) of M. oleifera leaves exposed to different pollution intensities in Jeddah city 
Variation in the content of some secondary metabolites (saponins, tannins and terpenoids) in $M$. oleifera leaves with the change in the intensity of air and soil pollution in Jeddah city, KSA, is represented in Figure 5. The heavy pollution in S2 by flaming fires, factories wastes and random waste disposal caused the accumulation of saponins in $M$. oleifera leaves with the uppermost value $(21.3 \mathrm{mg} / \mathrm{g} \mathrm{dw})$ throughout this study. In contrast, the lowermost accumulation of saponins $(11.6 \mathrm{mg} / \mathrm{g} \mathrm{dw})$ was documented in $\mathrm{S} 2$, which is exposed to air pollution by automobile exhaust. Tannins and terpenoids content was significantly varied with growth habitat from lowest value (4.35 and $1.59 \mathrm{mg} / \mathrm{g} \mathrm{dw}$, respectively) in $\mathrm{S} 3$, to highest one (6.06 and $5.90 \mathrm{mg} / \mathrm{g} \mathrm{dw}$, respectively) in $\mathrm{S} 1$.

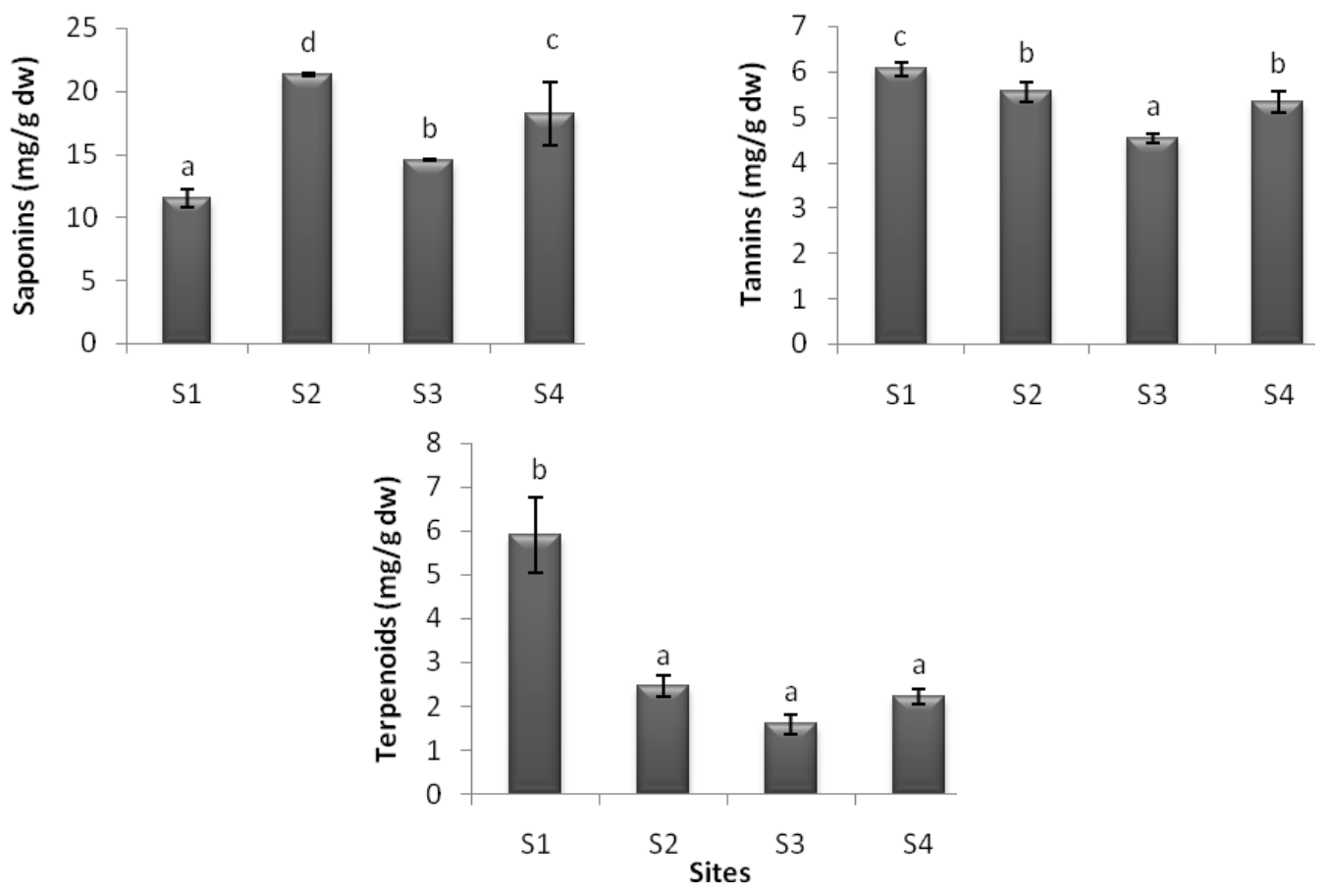

Figure 5. Variations in secondary metabolites (saponins, tannins and terpenoids) content $(\mathrm{mg} / \mathrm{g}$ $d w)$ of M. oleifera leaves exposed to different pollution intensities in Jeddah city

\section{Discussion}

The crisis of environmental pollution is one of the most important challenges facing man in our time. After the industrial revolution in the nineteenth century, the sources of water, air and soil pollution increased, which had a profound impact on the biosphere in which humans, animals and plants live. At the end, all sources of pollution affects human health negatively, either directly or indirectly. The plants are considered to be the most important indicators of evidence of pollution occurrence, and also contribute significantly to the removal of some environmental pollutants. In the present study, Moringa oleifera tree growing in differentially polluted habitats in Jeddah city, KSA was used as indicator on air and soil pollution. The variation in pollution intensity had significantly affected mineral content, photosynthetic pigments, primary and secondary metabolites and antioxidant status of $M$. oleifera leaves.

The present study showed that S2 soil (the most polluted site due to flaming fires and factories waste disposal) was more polluted with toxic metals as $\mathrm{Pb}, \mathrm{Cu}$ and $\mathrm{Mn}$. In the 
same time, trees growing in that area accumulated incredible quantities of heavy metals like $\mathrm{Pb}, \mathrm{Cu}, \mathrm{Mn}, \mathrm{Fe}$ and $\mathrm{Zn}$ in their leaves. Anthropological activities release large amounts of pollutants due to industrial effluents leading to pollution of ground water through the infiltration by soil which is a major issue (Vasanthavigar et al., 2012). Presence of heavy metals in soil and water can cause bioaccumulation affecting the entire ecosystem and pose harmful health consequences to all life forms. The main effects of these metals are inhibition of seed germination, hindering growth and production, affecting the yield of crops and viability of soil microflora (Sethy and Ghosh, 2013).

Photosynthetic pigments of $M$. oleifera leaves were affected by the pollution intensity of the growth site. Chlorophyll a content significantly affected within study accessions, the highest $\mathrm{Chl}$ a content was recorded in $\mathrm{S} 1$ (double public road exposed to automobile pollutions). Such results are in agreement with those obtained by Giri et al. (2013), who reported that air pollution significantly lowered Chl a content in Azadirachta indica, Mangifera indica, Nerium oleander and Dalbergia sissoo leaves. On the other hand, S4 and S2 leaves showed the least Chl b content. This result suggested that $\mathrm{Chl} b$ was more sensitive to air pollution than $\mathrm{Chl}$ a in M. oleifera leaves. Accordingly, the reduction in $\mathrm{Chl} b$ content was compatible with the results of Giri et al. (2013) who concluded that polluted sites have less Chl b content than non-polluted ones. Such reduction in Chl b content in air-polluted sites could be attributed to the accumulation of some metals in leaf tissues that increase chlorophyll degrading enzymes activity, inhibit chlorophyll synthesizing activity, or replace $\mathrm{Fe}$ and $\mathrm{Mn}$ ions in chloroplast proteins reducing their activity. In addition, the non-neutralized heavy metal ions stimulate formation of an excess of free radicals and slow down the turnover of chloroplasts proteins, mostly D1 protein (Lin and Aarts, 2012).

Carotenoids accumulation in plant leaves is a stress marker in most plant species. Carotenoids recorded the highest content in S2 leaves of M. oleifera. As a normal consequence of air and soil pollution, generation of free radicals and active oxygen species is stimulated. To prevent the deleterious effects of these oxygen species, plants have developed antioxidative mechanisms to detoxify such molecules. Carotenoids accumulation in response to heavy metals was observed by (Pinto et al., 2011) in Gracilaria tenuistipitata macroalga as they play crucial role in membrane stability, specially thilakoid membranes, as well as being natural antioxidants.

Soluble sugars and proteins were significantly lowered in heavily polluted accessions, comparable to those less polluted. Such result is in agreement with those obtained by Tzvetkova and Kolarov (1996), who concluded that decrease in total sugar content of in polluted sites could be attributed to the photosynthetic inhibition or stimulation of respiration rate. Also, decrease of soluble sugars could be an indicator of starch hydrolysis disturbance or altered carbohydrate metabolism in metal and gaseous polluted sites. The reduced carbon and sugar metabolism due to heavy metals and air pollutants might result from their probable interaction with ribulose-bisphosphate carboxilase active centre (Stiborov'a et al., 1987). The reduced protein content in polluted area could be attributed to impairment of pollutants with nitrogen metabolism or disruption in protein synthesizing enzymes. Such findings are in agreement with those of Rai (2016), who attributed that the enhanced rate of protein denaturation and breakdown of existing protein to amino acids are the main causes of protein reduction in response to air pollution. In addition, prolonged exposure to environmental pollutants results in depletion of the antioxidant enzymes as a result of oxidative damage to 
biological molecules, such as protein and DNA (Bebianno et al., 2005). Furthermore, heavy metals disorder protein metabolism either by forming complex with functional side chains or by substituting essential metal ions in metalloproteins (Tamás et al., 2014).

High pollution level in S2 and S3 accession resulted in higher levels of total lipids accumulation in plant leaves comparable to other ones. The same result was obtained by Nouairi et al. (2006) in Brassica juncea plants exposed to cadmium stress. They attributed this to the increase in vacuolar area where toxic metals are frequently stored. Previous work of Djebali et al. (2005) revealed variable effects of heavy metals on different fatty acids, as they have negative impact on $\alpha$-linolenic acid proportion, while other fatty acids were affected positively.

Our results revealed that the highest flavonoids content was found in the heavily polluted (S2) leaves. The results are in accordance with those of Robles et al. (2003) who reported that total flavonoids accumulation was indicator on ozone pollution in Pinus halepensis growing at five different polluted areas. Also, Betula pubescens leaves in strongly polluted areas significantly accumulated variability of some phenolics which might related to the effect of environmental contamination on shikimate and phenylpropanoid pathways (Loponen et al., 2001). Such increase in flavonoids content could be associated with its defensive role under conditions of environmental stress.

Variations in ascorbic acid level with growth accession were not effective. Previous work of Zengin and Munzuroglu (2005) showed that metal-treated (lead, copper, cadmium and mercury) bean seedlings showed significant higher ascorbic acid content. Such increase in ascorbic acid in polluted areas could contribute in raising the antioxidant capacity of stressed plants. Heavily polluted areas (S2 and S3) showed moderate DPPH activity, however less polluted areas showed oscillation in DPPH activity. The variation in total antioxidant activity between growth accessions could be attributed to the variable response of plant leaves to pollution intensity, in addition to the selective impact of contaminant kind on the antioxidant molecules.

The highest leaf free amino acids content was accounted for $M$. oleifera growing in S2 accession (most polluted). The increased accumulation of amino acids under metal toxicity might be due to its role in detoxifying heavy metal through making complexes with it, consequently assisting in the protection of the leaf and photosynthetic machinery from heavy metal injury (Rascio and Navari-Izzo, 2011). A leading mechanism in metal detoxification is the chelation of metals by metabolites rich in -SH groups. Hence, the content of non-protein thiols, which include thiol-rich peptides, glutathione, or other -SH rich compounds. A recent work of Nadgórska-Socha et al. (2017) demonstrated that thiol-containing amino acids content in Robinia pseudoacacia and Taraxacum officinale leaves were higher in the high traffic and emission regions.

Phenolic content in the leaves of $M$. oleifera only slightly differed between the various contaminated study sites. The uppermost phenolic content was detected in the leaves of S4 and S2. Mir et al. (2009) reported that total flavonoids and phenolics in Catharanthus roseus and Ocimum sanctum may serve as biomarkers of urban auto pollution as they showed a positive relationship with the vehicular pollution load. Rai et al. (2007) have also reported significant increase in total phenol contents in wheat under air pollution stress. Increase in phenolics under environmental stresses was monitored in many plant species as they play a crucial role in defense mechanisms against ROS damage. 
With respect to alkaloids accumulation, accession $\mathrm{S} 2$ recorded the maximum rate in M. oleifera leaves. These results are consistent with those obtained by Singh et al. (2000), who reported that alkaloid content of Datura innoxia was considerably accumulated in various plant organs in response to coal-smoke pollution. They attributed the increase in alkaloid content to a chemical adaptation or a defensive/protective strategy under stress. Alkaloids accumulation under stress conditions was reported in various plant species as Senecio longilobus (Briske and Camp, 1982), Lupinus angustifolius (Jansen et al., 2009) and Achnatherum inebrians (Zhang et al., 2011).

On the same pattern, the heavy pollution in S2 caused the accumulation of saponins in $M$. oleifera leaves comparable to other study sites. Szakiel et al. (2011) reviewed that plants belonging to the same species in different geographical zones may differ significantly in their content of secondary metabolites. This phenomenon was observed in many saponin-containing plants, including Panax ginseng, Panax quinquefolius and Panax notoginseng. The accumulation of saponins and other secondary metabolites in response to environmental factors is a part of an adaptive strategy leading to enhanced tolerance (Ramakrishna and Ravishankar, 2011). Nevertheless, tannins and terpenoids along this study showed variable accumulation in response to pollution intensity.

\section{Conclusion}

Trees and plants in the surrounding environment are considered the lungs of our life, on which most other organisms rely to obtain oxygen and energy. Civilization and urban life have become a major burden on the environment as a result of pollution of water, air and soil. In this study, Moringa oleifera trees growing in differentially polluted accessions in Jeddah city, KSA, showed that the intense pollution has a deleterious impact on the metabolic machinery and the physiological processes of the trees. As a responsive mechanism in heavily polluted accession, M. oleifera showed a diminution in chlorophyll, soluble sugars, soluble proteins, ascorbic acid, and terpenoid contents. On the other hand, lipids, flavonoids, amino acids, alkaloids and saponins were accumulated in the tree leaves.

\section{REFERENCES}

[1] Adedapo, A. A., Mogbojuri, O. M., Emikpe, B. O. (2009): Safety evaluations of the aqueous extract of the leaves of Moringa oleifera in rats. - Journal of Medicinal Plants Research 3(8): 586-591.

[2] Amaglo, N. K., Bennett, R. N., Curto, R. B. Lo, Rosa, E. A. S., Turco, V. Lo, Giuffrida, A., Curto, A. Lo., Crea, F., Timpo, G. M. (2010): Profiling selected phytochemicals and nutrients in different tissues of the multipurpose tree Moringa oleifera L., grown in Ghana. - Food Chemistry 122(4): 1047-1054.

[3] Bebianno, M. J., Company, R., Serafim, A., Camus, L., Cosson, R. P., Fiala-Medoni, A. (2005): Antioxidant systems and lipid peroxidation in Bathymodiolus azoricus from MidAtlantic Ridge hydrothermal vent fields. - Aquatic Toxicology 75(4): 354-373.

[4] Bligh, E., Dyer, W. J. (1959): A rapid method of total lipid extraction and purification. Canadian Journal of Biochemistry and Physiology 37(8): 911-917.

[5] Bradford, M. M. (1976): A rapid and sensitive method for the quantitation of microgram quantities of protein utilizing the principle of protein-dye binding. - Analytical Biochemistry 72(1-2): 248-254. 
[6] Briske, D. D., Camp, B. J. (1982): Water stress increases alkaloid concentrations in threadleaf groundsel (Senecio longilobus). - Weed Science 30(1): 106-108.

[7] Broadhurst, R. B., Jones, W. T. (1978): Analysis of condensed tannins using acidified vanillin. - Journal of the Science of Food and Agriculture 29(9): 788-794.

[8] Chang, C. C., Yang, M. H., Wen, H. M., Chern, J. C. (2002): Estimation of total flavonoid content in propolis by two complementary colorimetric methods. - Journal of Food and Drug Analysis 10(3): 178-182.

[9] Dillard, C. J., German, J. B. (2000): Phytochemicals: nutraceuticals and human health. Journal of the Science of Food and Agriculture 80(12): 1744-1756.

[10] Djebali, W., Zarrouk, M., Brouquisse, R., El Kahoui, S., Limam, F., Ghorbel, M. H., Chaibi, W. (2005): Ultrastructure and lipid alterations induced by cadmium in tomato (Lycopersicon esculentum) chloroplast membranes. - Plant Biology 7(4): 358-368.

[11] Dubois, M., Gilles, K., Hamilton, J., Rebers, P., Smith, F. (1965): Colorimetric method for determination of sugars and related substances. - Analytical Chemistry 28: 350-356.

[12] Fahey, J. W. (2005): Moringa oleifera: A Review of the Medical Evidence for Its Nutritional, Therapeutic, and Prophylactic Properties. Part 1. - Trees for Life Journal 1(5): $1-15$.

[13] Ganatra, T. J., Joshi, U. H., Bhalodia, P. N., Desai, T. R., Tirgar, P. R. (2012): A Panoramic view on Pharmacognostic, Pharmacological, Nutritional, Therapeutic and Prophylactic value of Moringa oleifera. - Intnational Resarch Journal of Pharmacy 3(6): $1-7$.

[14] Ghorai, N., Chakraborty, S., Gucchait, S., Saha, S. K., Biswas, S. (2012): Estimation of total terpenoids concentration in plant tissues using a monoterpene, linalool as standard reagent. - Protoc Exch 5. doi:10.1038/protex.2012.055.

[15] Giri, S., Shrivastava, D., Deshmukh, K., Dubey, P. (2013): Effect of air pollution on chlorophyll content of leaves. - Current Agriculture Research Journal 1(2): 93-98.

[16] Goyal, B. R., Agrawal, B. B., Goyal, R. K., Mehta, A. A. (2007): Phyto-pharmacology of Moringa oleifera Lam.-an overview. - Indian Journal of Natural Products and Resources 6(4): 347-353.

[17] Harbourne, J. B. (1984): Phytochemical Methods: A Guide to Modern Techniques of Plant Analysis. - Ghapman and Hall, London, pp. 4-120.

[18] Hiai, S., Oura, H., Hamanaka, H., Odaka, Y. (1975): A color reaction of panaxadiol with vanillin and sulfuric acid. - Planta Medica 28(6): 131-138.

[19] Horaginamani, S. M., Ravichandran, M. (2010): Ambient air quality in an urban area and its effects on plants and human beings: a case study of Tiruchirappalli, India. Kathmandu University Journal of Science, Engineering and Technology 6(2): 13-19.

[20] Jansen, G., Jurgens, H. U., Ordon, F. (2009): Effects of temperature on the alkaloid content of seeds of Lupinus angustifolius cultivars. - Journal of Agronomy and Crop Science 195(3): 172-177.

[21] Jindali, K. K., Singh, R. N. (1975): Phenolic content in male and female Carica papaya: A possible physiological marker for sex identification of vegetative seedlings. Physiologia Plantarum 33(1): 104-107.

[22] Lee, Y., Takahashi, T. (1966): An improved colorimetric determination of amino acids with the use of ninhydrin. - Analytical Biochemistry 14(1): 71-77.

[23] Lin, Y. F., Aarts, M. G. M. (2012): The molecular mechanism of zinc and cadmium stress response in plants. - Cellular and Molecular Life Sciences 69(19): 3187-3206.

[24] Loponen, J., Lempa, K., Ossipov, V., Kozlov, M. V, Girs, A., Hangasmaa, K., Haukioja, E., Pihlaja, K. (2001): Patterns in content of phenolic compounds in leaves of mountain birches along a strong pollution gradien. - Chemosphere 45(3): 291-301.

[25] Metzner, H., Rau, H., Senger, H. (1965): Studies on synchronization of some pigmentdeficient Chlorella mutants. - Planta 65(2): 186-194. 
[26] Mir, Q. A., Yazdani, T., Ahmad, S., Yunus, M. (2009): Total flavonoids and phenolics in Catharanthus roseus L. and Ocimum sanctum L. as biomarkers of urban auto pollution. Caspian Journal of Environmental Sciences 7(1): 9-16.

[27] Nadgórska-Socha, A., Kandziora-Ciupa, M., Trzęsicki, M., Barczyk, G. (2017): Air pollution tolerance index and heavy metal bioaccumulation in selected plant species from urban biotopes. - Chemosphere 183: 471-482.

[28] Nakao, M., Yamauchi, K., Ishihara, Y., Omori, H., Ichinnorov, D., Solongo, B. (2017): Effects of air pollution and seasons on health-related quality of life of Mongolian adults living in Ulaanbaatar : cross-sectional studies. - BMC Public Health 17(1): 1-12.

[29] Nouairi, I., Ammar, W. Ben, Youssef, N. Ben, Daoud, D. B. M., Ghorbal, M. H., Zarrouk, M. (2006): Comparative study of cadmium effects on membrane lipid composition of Brassica juncea and Brassica napus leaves. - Plant Science 170(3): 511519.

[30] Oser, B. L. (1979): Hawk's Physiological Chemistry. - McGraw-Hills, New York.

[31] Pinto, E., Carvalho, A. P., Cardozo, K. H. M., Malcata, F. X., dos Anjos, F. M., Colepicolo, P. (2011): Effects of heavy metals and light levels on the biosynthesis of carotenoids and fatty acids in the macroalgae Gracilaria tenuistipitata (var. liui Zhang \& Xia). - Brazilian Journal of Pharmacognosy 21(2): 349-354.

[32] Rai, P. K. (2016): Biodiversity of roadside plants and their response to air pollution in an Indo-Burma hotspot region: implications for urban ecosystem restoration. - Journal of Asia-Pacific Biodiversity 9(1): 47-55.

[33] Rai, R., Agrawal, M., Agrawal, S. B. (2007): Assessment of yield losses in tropical wheat using open top chambers. - Atmospheric Environment 41(40): 9543-9554.

[34] Rai, R., Rajput, M., Agrawal, M., Agrawal, S. B. (2011): Gaseous air pollutants: a review on current and future trends of emissions and impact on agriculture. - Journal of Scientific Research 55: 77-101.

[35] Rajput, H., Prasad, S. G. M., Srivastav, P., Singh, N., Suraj, L., Chandra, R. (2017): Chemical and phytochemical properties of fresh and dried Moringa oliferiea (PKM-1) leaf powder. - Chemical Science Review and Letters 6(22): 1004-1009.

[36] Ramakrishna, A., Ravishankar, G. A. (2011): Influence of abiotic stress signals on secondary metabolites in plants. - Plant Signaling and Behavior 6(11): 1720-1731.

[37] Rascio, N., Navari-Izzo, F. (2011): Heavy metal hyperaccumulating plants: how and why do they do it? And what makes them so interesting? - Plant Science 180(2): 169-181.

[38] Robles, C., Greff, S., Pasqualini, V., Garzino, S., Bousquet-Mélou, A., Fernandez, C., Korboulewsky, N., Bonin, G. (2003): Phenols and flavonoids in Aleppo pine needles as bioindicators of air pollution. - Journal of Environmental Quality 32(6): 2265-2271.

[39] Rockwood, J. L., Anderson, B. G., Casamatta, D. A. (2013): Potential uses of Moringa oleifera and an examination of antibiotic efficacy conferred by $M$. oleifera seed and leaf extracts using crude extraction techniques available to underserved indigenous populations. - International Journal of Phototherapy Research 3(2): 61-71.

[40] Saini, R. K., Manoj, P., Shetty, N. P., Srinivasan, K., Giridhar, P. (2014): Dietary iron supplements and Moringa oleifera leaves influence the liver hepcidin messenger RNA expression and biochemical indices of iron status in rats. - Nutrition Research 34(7): 630-638.

[41] Saini, R. K., Prashanth, K. V. H., Shetty, N. P., Giridhar, P. (2014): Elicitors, SA and MJ enhance carotenoids and tocopherol biosynthesis and expression of antioxidant related genes in Moringa oleifera Lam. leaves. - Acta Physiologiae Plantarum 36(10): 26952704.

[42] Sethy, S. K., Ghosh, S. (2013): Effect of heavy metals on germination of seeds. - Journal of Natural Science 4(2): 272-275.

[43] Singh, N., Ali, G., Soh, W. (2000): Growth responses and hyoscyamine content of Datura innoxia under the influence of coal-smoke pollution. - Journal of Plant Biology 43(2): 69-75. 
[44] Sreelatha, S., Padma, P. R. (2009): Antioxidant activity and total phenolic content of Moringa oleifera leaves in two stages of maturity. - Plant Foods for Human Nutrition 64(4): 303-311.

[45] Stiborov'a, M., Ditrichov'a, M., Brezinova, A. (1987): Effect of heavy metal ions on growth and biochemical characteristics of photosynthesis of barley and maize seedlings. Biologia Plantarum 29(6): 453-467.

[46] Sun, Y. I., Oberley, L. W., Li, Y. (1988): A simple method for clinical assay of superoxide dismutase. - Clinical Chemistry 34(3): 497-500.

[47] Szakiel, A., Pkaczkowski, C., Henry, M. (2011): Influence of environmental abiotic factors on the content of saponins in plants. - Phytochemistry Reviews 10(4): 471-491.

[48] Tamás, M. J., Sharma, S. K., Ibstedt, S., Jacobson, T., Christen, P. (2014): Heavy metals and metalloids as a cause for protein misfolding and aggregation. - Biomolecules 4(1): 252-267.

[49] Tzvetkova, N., Kolarov, D. (1996): Effect of air pollution on carbohydrate and nutrients concentrations in some deciduous tree species. - Bulgarian Journal of Plant Physiology 22(1-2): 53-63.

[50] Vasanthavigar, M., Srinivasamoorthy, K., Prasanna, M. V. (2012): Evaluation of groundwater suitability for domestic, irrigational, and industrial purposes: a case study from Thirumanimuttar river basin, Tamilnadu, India. - Environmental Monitoring and Assessment 184(1): 405-420.

[51] Zengin, F. K., Munzuroglu, O. (2005): Effects of some heavy metals on content of chlorophyll, proline and some antioxidant chemicals in bean (Phaseolus vulgaris L.) seedlings. - Acta Biologica Cracoviensia Series Botanica 47(2): 157-164.

[52] Zhang, X., Li, C., Nan, Z. (2011): Effects of salt and drought stress on alkaloid production in endophyte-infected drunken horse grass (Achnatherum inebrians). Biochemical Systematics and Ecology 39(4-6): 471-476. 